\title{
Online, Digital or Distance? - Spread of Narratives in ICT-Supported Education
}

\author{
Andrea Tick \\ Óbuda University \\ Judit Beke \\ Budapest Business School
}

\begin{abstract}
Digitization and digitalization have transformed educational practices. The COVID-19 pandemic triggered a sudden change in the mode of the delivery of education and forced schools and universities to relocate education to digital platforms and revolutionize educational processes. The shift to online platforms brought terms like digital education/learning, online education/learning, blended and hybrid education/learning to the forefront, while traditional terms like eLearning, distance learning and mobile learning remain popular. This paper studies these terms and by backing the educational process redesign with ICT development and the time-space-group dimensions, it highlights the viral nature of the narratives of the terms.
\end{abstract}

Keywords: blended learning, digital learning, hybrid learning, narratives, online learning, pandemic

\section{INTRODUCTION}

The advent of the Internet, the rapid development and revolution in information technology (IT) and information and communication technology (ICT) have drastically improved human life. The presence of technology is visible in almost all aspects of day-to-day living and has become the lifeblood in society and in the world of business. The proliferation of digital technologies in education continuously forces educators to improve their methodologies, change the mode and medium of delivery or even revolutionize education practices. Throughout the past few decades, from the appearance of computers in education, first a slow then a faster shift in platforms from traditional classrooms to computer labs can be traced. Meanwhile, societal changes due to the proliferation of the internet into homes has resulted in a transition from offline to online education. Furthermore, modern digital technologies have called a structural change in educational modes and methods, and especially due to the COVID-19 pandemic, which forced all educational institutions, from primary to tertiary levels, to radically change their educational practices. This resulted in a sharp turn in best practices and made exclusively digital and online education/learning accessible to students.

On the other hand, throughout the decades the terms associated with digitalization in education have changed periodically. Different terminologies have been linked to different stages of development in computerized education. While the basics of educational practices have not changed, the delivery medium and the focus of the learning process have changed moving toward two extreme poles of the key 
determining features of digitalized education. These terms that can be referred to as narratives follow the patterns of a pandemic, i.e. they go viral, they have their own birth, virulent period, decline and death (Schiller, 2020).

This paper looks at several terms and concepts in relation to digitalized education. It strives to make significant differences in their definitions in correlation to IT and ICT development, the time-space-group dimensions placing the changes in Venkatraman's business process redesign concept, while exploring the narrative nature of the concepts in question. The following terms will be put under scrutiny: distance and remote learning, e-learning, digital and online learning, mobile learning, blended and hybrid learning.

The paper is an exploratory paper that uses secondary research and data. The chapters introduce the applicability of business process redesign (BPR) in educational modes and methods. Then, with the timespace-group triangle, it presents the digital development in education and finally, it links these development curves to the life cycles of narratives.

The second chapter aims to shed new light upon the evolutionary and revolutionary changes in educational modes and methods and presents how the development stages in educational methodology can be matched with the different stages in business process redesign. Furthermore, the chapter covers the timespace-group triangle to support the discussion in the third chapter, which focuses on the various terms and their life cycle in the last fifty years. The discussion presents the life of the different terms in relation to ICT development and brings on the virulent characteristics of these terms in the last of the previous century.

\section{EDUCATIONAL PROCESS REDESIGN}

The World of Bits has permeated every field of life, business and education and has transformed the way we live, do business, and educate. The technological development accompanies and transforms not only business processes but educational processes and educational methodologies as well. The deployment of the most up-to-date computers, ICT technologies in educational practices triggered different directions in the tools, devices and apps that are being used. The possibilities in computerized and digitalized technologies have given impetus to educational practices and similarly to business practices technological innovation has replaced traditional processes.

\section{The Venkatraman Model in Higher Education}

The technological developments mainly in the ICT industry throughout the last half of the century joined with the digital and later the smart boom, and the immense rate of digitization in all fields of industry and business, especially in the service industry tremendously changed processes and best practices. "Computer and communications technology has applications in all sectors of education", argued Ferguson \& Wilson. (2001). In the last two decades mobile technology and the smart boom opened new doors and supported the development of apps for learning on the move. The spread of the internet, the connectedness of people made institutions transform the delivery channels and the forms of learning in education. However, the challenges and the potentials occurring with the deployment of ICT that radically changed the business workflow at higher educational institutions did not necessarily produce consistent improvements in educational practices and methodologies and did not result in the deployment of the most up-to-date methodological changes. Not only traditional educational methodologies face challenges due to digitization but at the same time e.g. networking technology opens the pool of opportunities for changes in the mode of teaching. Educational institutions have reacted by integrating the available technologies in the educational processes, thus ensuring modernization and improving the quality of education to satisfy the needs of the incoming generations. As generations alternate from baby boomers through digital immigrants to digital natives (McCrindle, 2018), so must the educational methodology change. It must be tailor-made for the needs of the $\mathrm{Z}$ and soon for the $\alpha$ generations. Consequently, the flow of development in teaching methodology and the rate of integration of digital technologies show similarities with that of business processes. As in the field of business an unexpected, sudden technological innovation or a pandemic can put off the usual methodological flow. This can also cause a breakthrough, open a new orbit with higher quality, more digitalized education. A weak signal or a wild card like the COVID-19 pandemic can bring 
out such solutions that already existed but was not deployed and used by lecturers and institutions. The existence of digital solutions does not mean that lecturers are immediately familiar with the technology, a pandemic can force educational institutions to revise their practices, redefine and redesign their "business processes" and integrate the already existing technologies in their educational practices.

In 2021, during the second wave of COVID-19 most of higher educational institutions that have already combatted the emergency remote education challenges, practically integrated fully digitalized education in their courses and are underway a structural and methodological change concerning their educational practices.

Beyond such unavoidable consequences of the pandemic, the labor market as well as the needs of the digital generations push methodological changes forward. The three pillars that underline the methodological and structural changes, namely digitalization, methodological challenges such as the core of education shifted to competence-based education, and the attitude and behavioral changes of generations jointly boost educational process redesign in the 21 st century. The technological support of learning and teaching started with isolated computer assisted learning, then the solid support of ICT technologies turned computer assisted learning to offline eLearning while the appearance of connectedness - networks allowed the birth of online learning. In parallel the seamless slide of the term 'digital' into the unconsciousness of people lands next and gains ground among the terms.

As the digital natives enter into higher education, their needs of competence-based, project-based and problem-based education as examples also challenge universities to introduce novel methodological approaches in order to maintain their students' attention and offer high quality education to gain a competitive advantage (Figure 1).

\section{FIGURE 1 \\ THREE DRIVING FORCES OF CHANGES IN HIGHER EDUCATIONAL PRACTICES (DEVELOPED BY AUTHORS)}

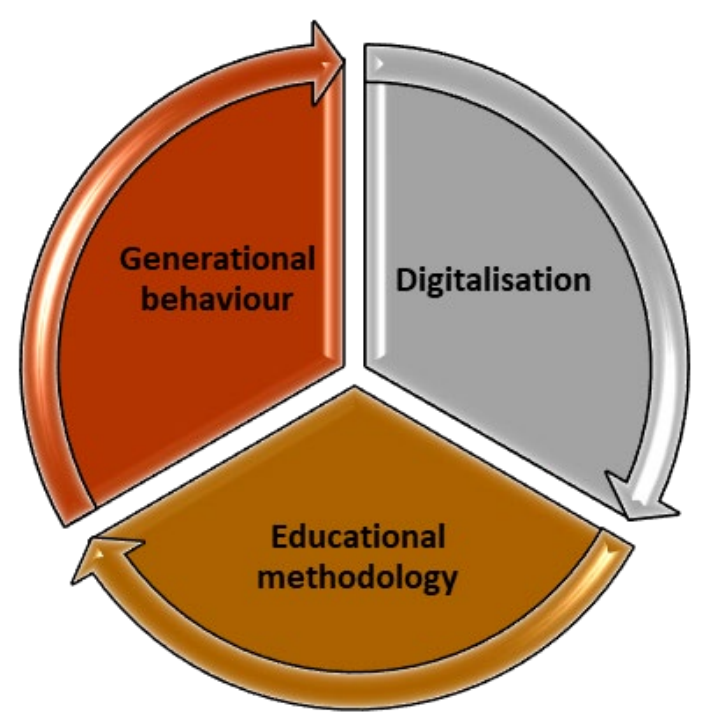

These forces with their own development drive educational modes and methods to develop even in higher education, inspire the integration of digital tools and devices and enables the reform of the delivery mode and of the structure of education. The first wave of the COVID-19 pandemic forced higher educational institutions to migrate their education onto digital platforms at short notice, thereby stepping onto the next stage in its development after the evolutionary stages (Figure 2).

Public as well as higher education now has the possibility to step into a revolutionary phase of development in terms of instructional methodology. In this crisis, several similarities could suddenly be found with the development of business processes. Due to the physical closure of schools and universities 
education was forced to enter a phase of Educational Methodological Redesign (EMR). The last half of the previous century has proved that technological development, together with changes in society, shifts all kinds of processes in business, education or even health service provision from an incremental, evolutionary phase to a more radical, revolutionary phase (Venkatraman, 1994). At present the second wave of COVID19 has proven that the shift is now underway, not only in Hungary, and educational institutions are adjusting their educational strategies and policies to the changed circumstances and reconsider the proportion of offline and online contact teaching.

\section{FIGURE 2 \\ EDUCATIONAL METHODOLOGY REDESIGN (DEVELOPED BY AUTHORS BASED ON VENKATRANAM (1994), FERGUSON \& WILSON (2001)}

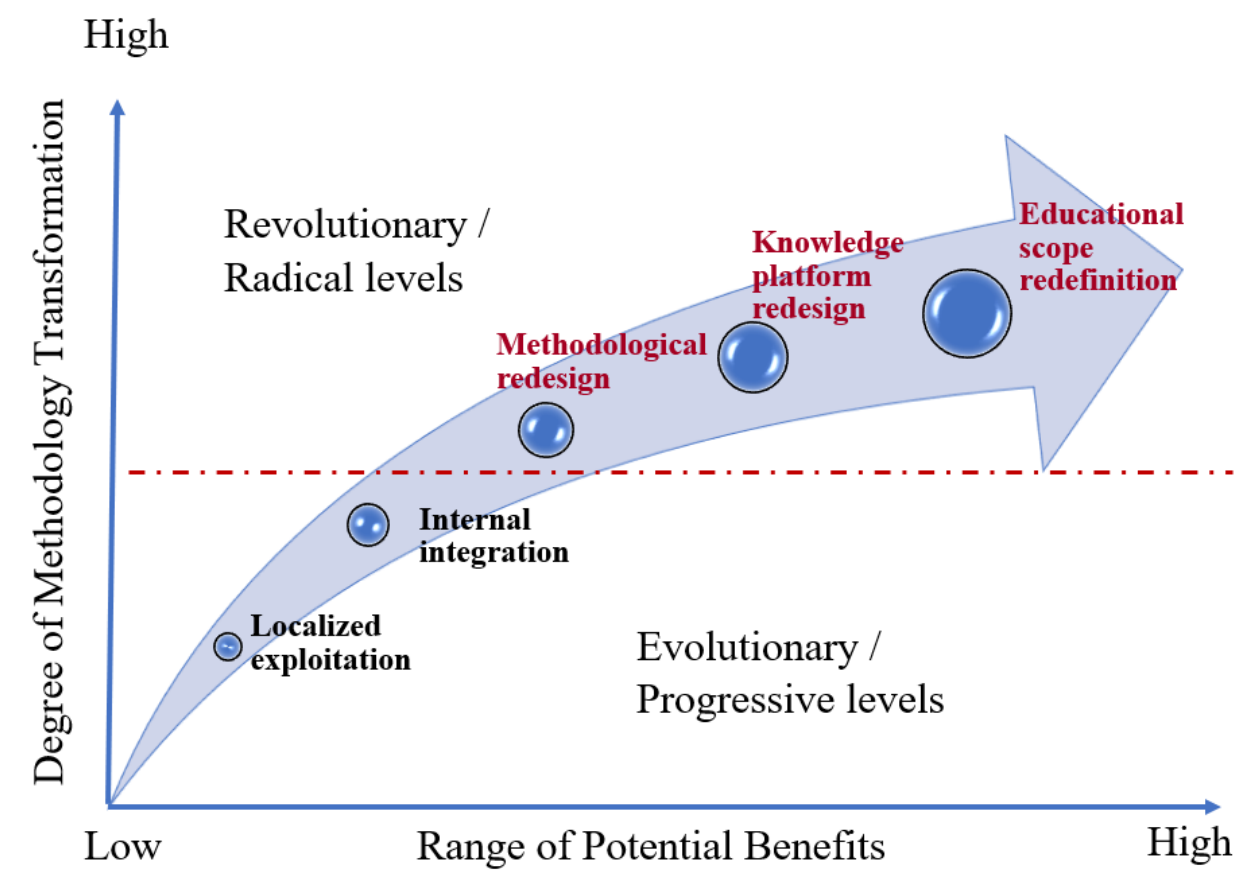

Source: developed by authors based on Venkatraman (1994) and Ferguson \& Wilson (2001)

Ferguson and Wilson (2001) argue that educational institutions have already undergone through the progressive phases regarding the mode and method of teaching. According to them "most of the current efforts to make use of computer and communications technology within education fall within the early and progressive stage of IT implementation" (Ferguson \& Wilson, 2001). However, due to the development of ICT integration - rather than just IT development as claimed by (Ferguson \& Wilson, (2001) - in educational technologies, the development of applications and web-based technology, furthermore the deployment of online/digital education due to COVID-19 pushed educational practices to the radical/revolutionary phase lately, in which online learning being real-time question the status quo and desires for a reappraisal of digital education. Even such educational institutions which were stuck at the progressive /evolutionary level have to open towards the involvement of digital technologies and revise their delivery modes and methods. The success or failure of online education during the pandemic will determine how education will be restructured and how digital educational methodologies will be integrated in the content delivery after the pandemic. By applying the Venkatraman model for educational process redesign the paper focuses on finding similar waves of narrative lives of the terms used during the past fifty years for the mode and method of teaching and learning when it utilizes ICT. 


\section{The TIME-SPACE-GROUP-LINKED Dimension Framework for Terminology Definition}

"Education is people-centred activity" (Ferguson \& Wilson, 2001) and as such, the success of education highly depends not just "on the sensitive implementation of fundamental IT-based change" but on the social well-being, the personal feelings and emotions as well as on the perception of the parties involved in the process of digital learning. The time-space-group model elaborated for distance learning by (Miller and Padget, 1998) well depicts the developmental changes in the mode and methods of education. By now the model needs to be extended by a fourth dimension, namely "linked". Each of these dimensions have two poles, while two aspects can be assigned to the group dimension, namely the size of the group and the similarity of the group members (Tick, 2006):

- Time - The time factor (synchronous or asynchronous) represents a significant feature according to which the learner can choose to participate in the learning environment in real time or decides to adopt individual time scheduling. In both cases the participation of a tutor is unavoidable who guides and helps the learner to cope with the learning material.

- Place - The place factor (same or different) distinguishes distance learning from the conventional way of education.

- Group size - The group size factor means individual learning or being a group member in the learning process.

- Group membership - The group membership factor (same or different) applies when delivery of content is conducted in the same or different groups using different technologies.

- Linked - This factor determines whether learning and teaching is conducted online or offline.

The evolving terms in education linked to the technological development and the focus shift to more individualized learning and lifelong learning can be assigned to the intersections of the poles of the dimensions. From the asynchronous mode of computer-based learning through self-learning MOOC courses to the synchronous video conferencing education has already entered the phase of synchronous virtual classes in hybrid learning involving different group of students. The perception of time and space has significantly changed in the information society; time and space come closer and closer thus students wish to utilize any time and space available for them to enhance their knowledge (Miller \& Padget 1998). In addition, citizens of the information society are not just doers but thinkers, problem-solvers as well as communicators (Jacqueline \& Brooks, 1999). They take networks and apps for granted and long for instant availability of information and knowledge on the web. As a result, online delivery of teaching become a regular practice, while the application of methodologies from traditional type of education has raised the question how well education is prepared for real-time online teaching.

The following chapter explores the terms distance learning, remote learning, digital learning, elearning, mobile learning and online learning running and categorizing along the above dimensions. In the discussion the lifecycles of these terms as narratives are discussed and linked to the ICT development stages arguing for the usage of certain terms at the expense of others. It is argued that instead of education the word learning is more frequently used in the above expressions and the progressive and radical changes on the mode and methods of teaching matches the life of the terms in questions.

\section{TERMINOLOGY AND CONCEPTS}

Due to a change in society, the big boom in ICT, the maturing of the digital natives in the last couple of decades, the emphasis has shifted from learning in classrooms towards learning individually and online, encouraging autonomous, independent and lifelong learning. The proliferation of the Internet, the urge of elearning in society has brought certain methods and approaches to light, while others seem to disappear in the shadow.

The chapter examines the different terms, compares them along the time-space-group-linked dimensional framework, places them in the educational methodology redesign concept and assigns an ICT development stage to the terms and concepts. 


\section{Distance Learning vs. Remote Learning vs. Digital Learning}

Simonson et al. (2019) refers to four key components of distance education: a) separation of learners and instructors in time, space and intellectually, b) interaction among the learners and instructors can be either synchronous or asynchronous through the use of electronic or non-electronic media, c) the learning experience is shared among learners and instructors, d) it is institutionally based (vs. self-study), planned and is a systematic activity.

According to Simonson et al. (2019) distance education (or distance learning) is formal education where the learners and what is being learnt are separated in time and/or space (hence the word distance). Picciano (2001) defines the term distance learning as an educational process in which the teachers and the students are separated physically but he does not specify the technology used. The learners, what is being learnt and the instructors are connected by interactive telecommunication systems.

Several authors note that the concept of distance learning is not new, correspondence course have existed since the 1800s. Technological advances, computer-mediated communication and the Internet has given further impetus to the development of distance education, however, distance learning is not necessarily online learning, and online learning is not necessarily distance learning (Bates, 2005). Similarly, it is important to make a distinction between "distance education" and "e-learning" which are not synonyms (Anohina, 2005). Distance learning implies a distance between geographically remote students and teachers. According to Anohina (2005) distance learning is broader than e-learning because it covers both non-electronic and technology-based media of delivery. It is important to mention that the term "online learning" is used as an umbrella term, the broadest term, that generally refers to using online tools and technology for learning that is accomplished via a computer (for example in Carliner, 2004; Guri-Rosenblit, 2011; Dorsah, 2021). Online learning most often but not necessarily refers to learning over the Internet. The most widely used synonymous terms are computer -aided, -assisted, -augmented, -enabled, -enhanced, -supported learning (Anohina 2005).

Remote learning is defined as a temporary shift of instructional delivery from a face-to-face classroom to a virtual classroom. The classes are at one-time scheduled times and the content is originally designed for a face-to-face class. The synchronous classes are delivered via an online platform where learners can interact with the instructor as they would do in a traditional classroom. It is seen as an opportunity for groups of students and the instructors to remain connected even when face-to-face, blended or hybrid delivery modes are not an option, typically in emergency or crisis situations (Hodges et al., 2020; Dorsah, 2021).

Remote learning is different from online learning as the timing of the class is less flexible, and the learners can only interact with the instructor when invited to communicate. Hodges et al. (2020) defines emergency remote teaching as a quickly set up, reactive, fully online solution for instruction that temporarily cannot be delivered face-to-face. Such courses return to the traditional format when the emergency situation is over.

Digital learning (d-learning) is an instructional practice where the time and location of learning are independent. According to Basak et al. (2018), digital learning provides expanded learning opportunities as it connects learners and instructors who work remotely, outside the traditional on-site learning environment. Collaboration and communication of learners and instructors are easy, and personalized supplementary instruction or supervision is available through online delivery. The interactive digital learning content is easily accessible for the group of learners; however, strong digital skills are required from the instructor and learner alike. This type of learning is facilitated by the use of digitized technology and the Internet that enables learners to learn on their own, at their own pace, in their own style, anytime, anywhere. The technology and the software used can change the instructors' pedagogy and role.

\section{Blended Learning vs. Hybrid Learning}

Blended learning is a learning model which combines traditional in-person, face-to-face classroom interaction at educational institutions and ICT applications regardless whether the students and instructors are either physically separated or not. Blended learning can take place at anytime, anywhere, and students, who have Internet access, can benefit from the use of technology in the learning process (Yigit, et al. 2014). 
Since distance delivery is assisted by face-to-face delivery, the learning schedule can be more flexible and optimal and the learning experience can be improved as compared to traditional education (Yigit, et al. 2014). In blended learning, the individuals working on-site and on-line are the same, the learning process is sequential (Steele, 2020). Kaur (2013) defines the blended learning model as the combination of a synchronous or asynchronous learning environment, a selected instructional medium that supports instruction and an appropriate instructional strategy. The definition has evolved over time, and it combines or blends online and offline elements and structured and unstructured elements as well.

According to Cronje (2020), the definition of blended learning should include context, theory, method and technology, therefore the author recommends the following all-inclusive definition: "The appropriate use of a mix of theories, methods and technologies to optimize learning in a given context.".

Basak (2018), Hrastinsky, 2019 and Acer (2020) define blended learning and hybrid learning as synonyms: instruction occurs away from home, the time, place, path, or pace of the online delivery of instruction is partly controlled by the learner. More recent developments such as flipped/inverted classes are considered to be a type of blended learning. Several authors suggest that hybrid learning is a new pedagogical approach where instructors deliver the class face-to-face, on-site for a group of learners, however, it is combined with simultaneous remote but synchronous/parallel, computer-mediated instruction for a different group of individuals (Steele, 2020).

\section{eLearning vs. Mobile Learning}

The term electronic learning or e-Learning (also spelt as eLearning, elearning, e-learning) is used to describe synchronous or asynchronous teaching and learning practices for which electronic technologies, digital or online tools and media such as DVD, CD-players, smartphones, TV or the Internet are used (GuriRosenblit, 2011; Basak et al., 2018, Kolakowski et al., 2020). The main aim is not necessarily to cover distances between the physically separated learners and the instructor, but to use technologies in order to make learning more engaging for all learners, not only for distance learners (Guri-Rosenblit, 2011).

Koohang et al. (2005) define e-learning where education is delivered online on a mass customized basis using various electronic media to reduce expenses and increase revenues at educational institutions. According to Anohina (2005) e-learning takes places via any electronic medium, therefore it can involve non-networked computer-based learning as well.

According to Ozuorkun (2012) e-learning can be an alternative and a complementary to traditional education. It is more learner-centred since the learners can work self-paced whenever they have access to a computer and the Internet, however, it reduces the interaction between the learners and the instructors. Synonyms that are used to describe e-learning are computer-based learning, multimedia-based learning or distance learning.

Ozuorcun (2012) summarizes the advantages of mobile learning as follows: learning can happen when the learner is willing to learn, in any place, at any time. Information, knowledge and experience can be shared through interactive systems informally and fast. According to Basak et al. (2018) m-learning is a platform for interaction opportunities among learners and instructors who are physically separated, i.e. not at a fixed traditional classroom environment. The perspectives of m-learning are the mobility of technology, the mobility of learning and the mobility of the learner.

The term mobile learning is used to refer to learning by using portable mobile computational devices, complex applications and wireless networks while on the move (Kothamasu, 2010; Park, 2011; Parsons, 2014; Basak, 2018) however, Parsons (2014) pointed out that learners rarely learn while on the move. The main purpose of m-learning activities is to enhance and support the learning experience in both distance learning and face-to-face classroom environments (Park, 2011; Brown \& Mbati, 2015). The authors agree that the main advantages of m-learning are enhanced user experience, ready accessibility, ability to enable informal learning anytime, anywhere. M-learning can bridge geographical distances and can provide a collaborative learning environment for groups of learners.

Basak (2018) suggests that digital learning is the broadest term which includes e-learning, and mlearning is involved in e-learning. Brown et al. (2015) draws the attention to the fact that mobile learning 
is not necessarily learning by using mobile phones. The use of mobile technology is not the driver but the enabler, i.e. it is used to enhance the learning experience.

\section{DISCUSSION}

\section{The Life of the Narratives}

The rate of integration of ICT technologies, activities, communication networks, and digital possibilities have always had a significant influence on the delivery of education and these progresses have driven structural and methodological changes in education. By examining the advancement of ICT and its inclusion in the delivery method of teaching and learning, the terms and concepts discussed follow a similar life as a pandemic. Schiller (2020) argues that narratives in economics behave similarly as pandemics, have influence on economics processes and their life can be described by mathematical models used for epidemics and pandemics in medical sciences. Pandemics have their viral, mature and declining phase (similarly to a product life cycle used in marketing), so as narratives in economics. All the terms and concepts that the authors explored in the previous chapter can be related to a stage in ICT development, to an evolutionary/progressive or revolutionary/radical stage in the EMR model, and a shift can be noticed in the degree of the time-space-group-linked matrix. As gossips spread so do the use of terms go viral and are used more and more frequently in the profession throughout the years or even decades. Immediately as a new technological innovation is introduced and is accepted to a great extent, a new narrative emerges and becomes viral while the older one declines and gets forgotten (Schiller, 2020) Who remembers the term CALL (computer-assisted language learning) or frequently use distance learning anymore? As viruses have more waves so might these narratives gain stress in time and go viral again.

The viral period of the terms discussed in the previous chapter can be detected by the frequency use in books, research articles and the news. The Google Ngram viewer gives an exemplar of the viral stages of these terms. The Google Ngram viewer is an online search engine that charts the relative frequencies of any set of search words and phrases, using a yearly count of n-grams found in millions of books in the Google Books corpus printed between 1500 and 2019. The corpus enables quantitative analysis of cultural and linguistic trends (Lin et.al., 2012) The source is limited to the pool on Google Books but well depicts the viral nature of these phrases. At first the terms CALL, eLearning, distance learning, online learning, digital learning and mobile learning were selected, then blended learning and hybrid learning are to be on display on the Ngrams so as to see their virulent periods and how these terms live next to each other. The search on the Ngram viewer resulted in a much higher relative frequency when the word learning was connotated instead of education, thus the phrases ending with learning were searched.

Figure 3 and 4 present all the terms selected between 1950 and 2019, separating British and American English usage. British and American English results make a difference in these narratives - the search in the English corpus gave a very similar result to the American English corpus findings. 
FIGURE 3

THE NGRAM CHART OF THE TERMS “CALL”, “ELEARNING”, “DISTANCE LEARNING”, “ONLINE LEARNING”, “DIGITAL LEARNING” AND “MOBILE LEARNING” IN AMERICAN ENGLISH CORPUS BETWEEN 1950 AND 2019

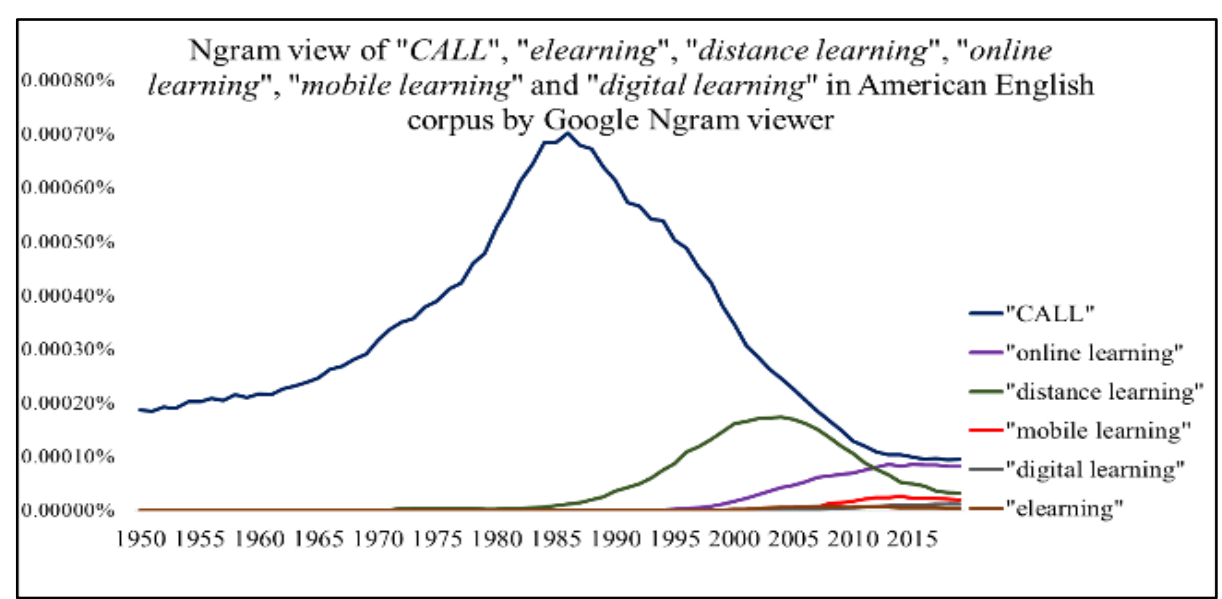

(Source: Google Ngram Viewer) (Developed By Authors)

The charts distinctly depict that $C A L L$ had a virulent period from the birth of the computer till the PC boom and the proliferation of the internet and networks, while align with its decline the term distance learning - enabled by ICT technology and the web - started to spread.

The smart boom brought the end of the virulent period of distance learning while online learning went viral, and it is still in its first wave. The narrative for mobile learning was born with the smart boom. In British English CALL had a second, not as virulent phase as the first one after 2010, and the virulent period of distance learning was much more infectious than in American English. While the narrative for online learning shows a continuous growth both in English and in American English, in British English it was not contagious from 2005, but after 2010 the use of the term became quite frequent again and it is frequently used in literature.

FIGURE 4

THE NGRAM CHART OF THE TERMS “CALL”, “ELEARNING”, “DISTANCE LEARNING”, “ONLINE LEARNING”, "DIGITAL LEARNING” AND “MOBILE LEARNING" IN BRITISH ENGLISH CORPUS BETWEEN 1950 AND 2019

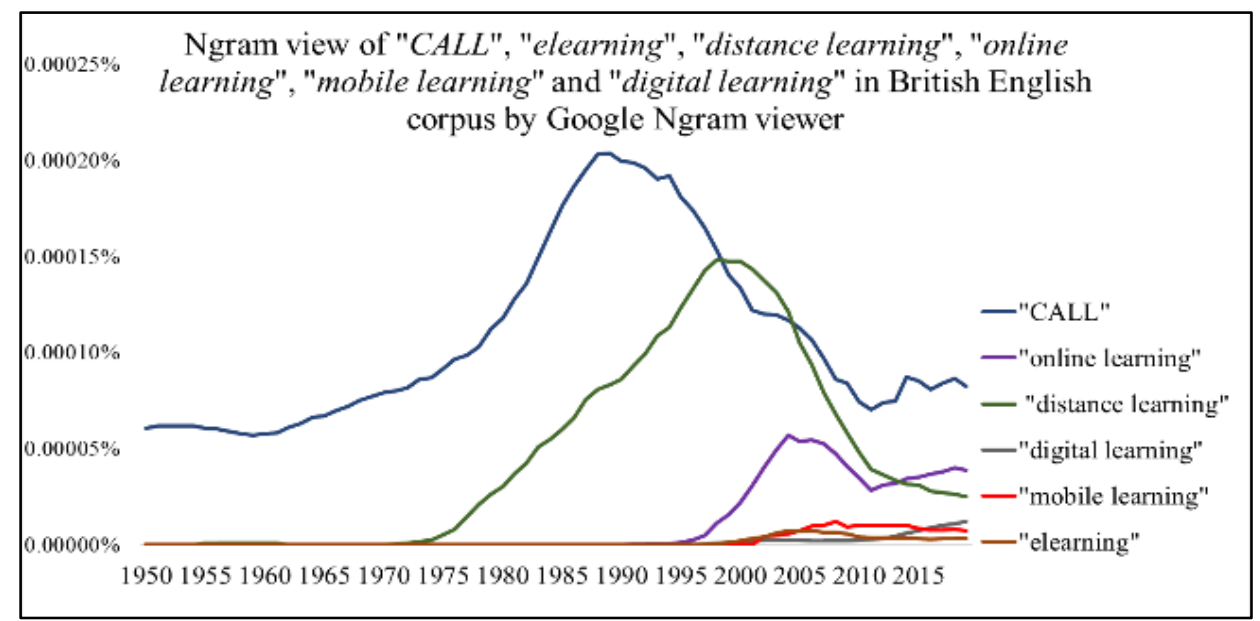

(Source: Google Ngram Viewer) (Developed By Authors) 
Figure 5 and 6 present the life of the above terms without CALL between 1950 and 2019. The epidemic of distance learning shows a shorter virulent period in British English than in the American one, and the behavior of online learning, which seems to have replaced the term distance learning, is different in American and British English.

\section{FIGURE 5}

\section{THE NGRAM CHART OF THE TERMS "ELEARNING", "DISTANCE LEARNING", "ONLINE LEARNING”, “DIGITAL LEARNING” AND "MOBILE LEARNING” IN AMERICAN ENGLISH CORPUS BETWEEN 1950 AND 2019}

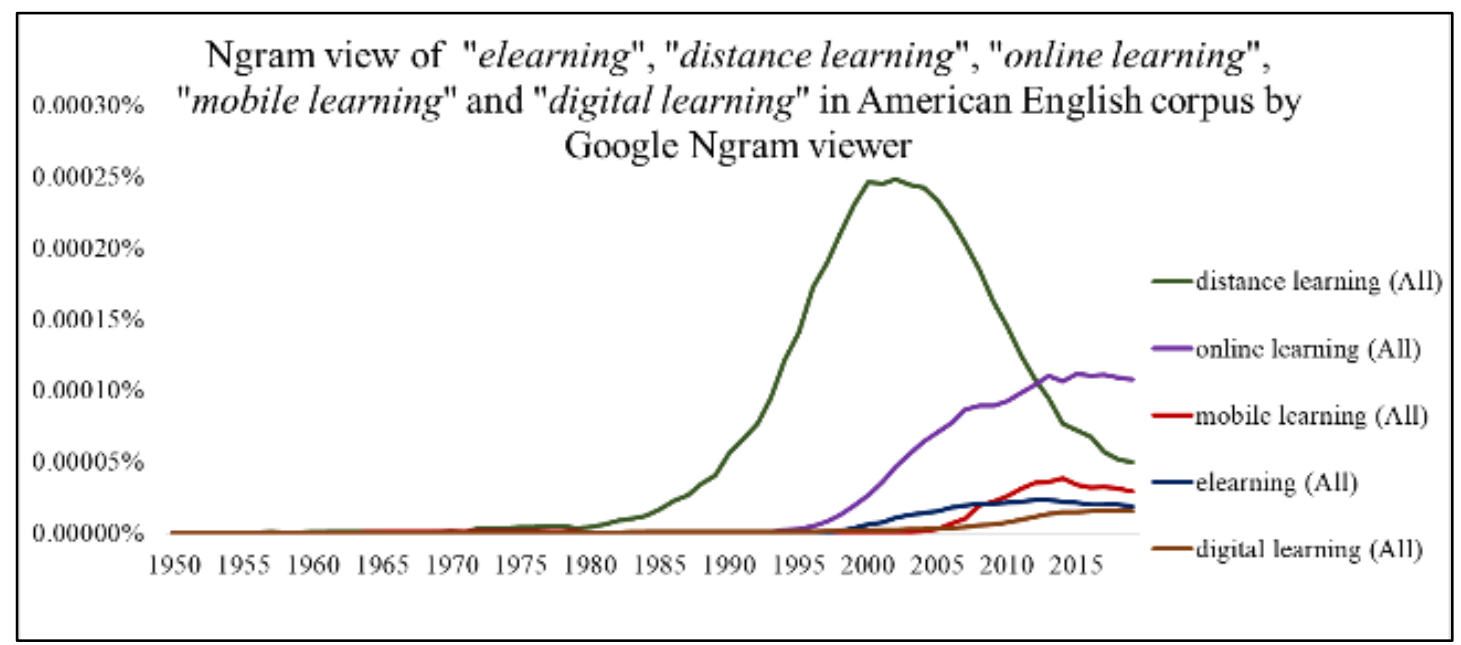

(Source: Google Ngram Viewer) (Developed By Authors)

The search takes into account the different spelling and capitalization of the terms, it was run case insensitive, for instance all "eLearning", "elearning", "e-learning", "e-Learning" etc. were all included in the search. While the use of the term online learning linked to the internet boom is continuously increasing in American English from 1995, showing a slight decline at the end of the last decade, in British English the first wave of the term online learning calmed down during the last decade of the 20th century but became infectious again after 2010. Since 2010, the use of the term digital learning - linked to the digitalization boom - behaves similarly as online learning in British English, the use of the term is continuously increasing both in British and American English. According to the Ngram the term elearning already reached its peak infectious period around 2010 and it is less frequently used nowadays. 


\section{FIGURE 6}

THE NGRAM CHART OF THE TERMS "ELEARNING", "DISTANCE LEARNING", "ONLINE LEARNING", "DIGITAL LEARNING" AND "MOBILE LEARNING" IN BRITISH ENGLISH CORPUS BETWEEN 1950 AND 2019

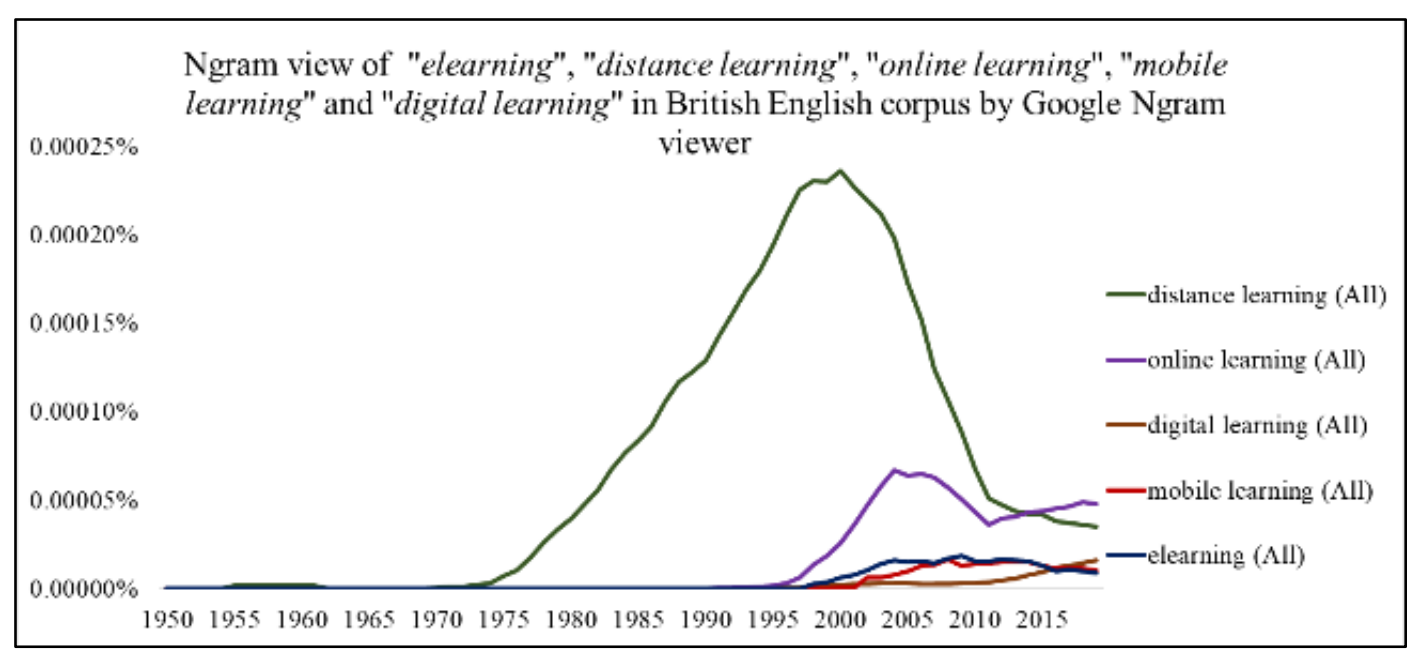

(Source: Google Ngram Viewer) (Developed By Authors)

Comparing British and American English to the German, French, Spanish and Italian occurrences, differences can be found in the usage of certain terms (Figure 7 - Figure 12). Online learning is rather used in English while elearning is the most popular term in German, French, Spanish and Italian, despite of the fact that these terms are not infectious any more in these languages.

\section{FIGURE 7}

THE NGRAM CHART OF THE TERMS "ELEARNING", “ONLINE LEARNING", "DIGITAL LEARNING" AND “MOBILE LEARNING" IN AMERICAN ENGLISH CORPUS BETWEEN 1992 AND 2019

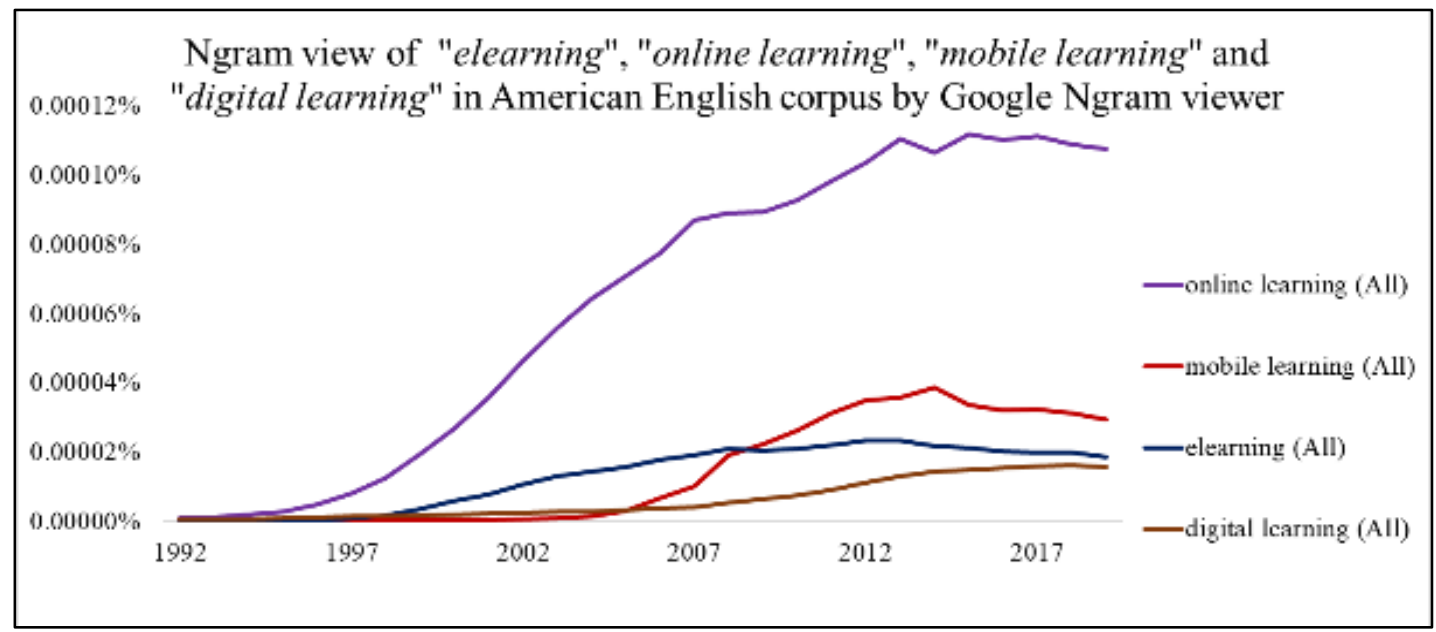

(Source: Google Ngram Viewer) (Developed By Authors) 
FIGURE 8

THE NGRAM CHART OF THE TERMS “ELEARNING”, “ONLINE LEARNING”, "DIGITAL LEARNING” AND “MOBILE LEARNING” IN BRITISH ENGLISH CORPUS BETWEEN 1992 AND 2019

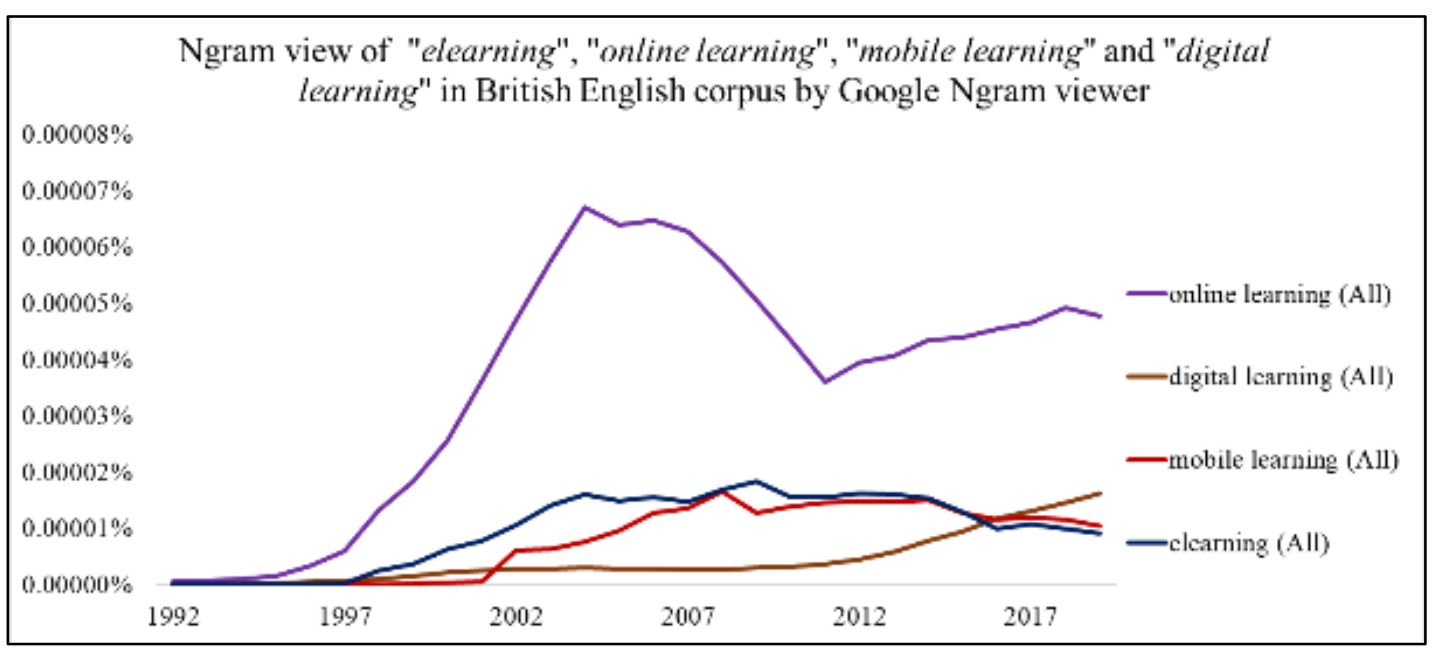

(Source: Google Ngram Viewer) (Developed By Authors)

FIGURE 9

THE NGRAM CHART OF THE TERMS "ELEARNING", “ONLINE LEARNING", "DIGITAL LEARNING" AND “MOBILE LEARNING” IN GERMAN CORPUS BETWEEN 1992 AND 2019

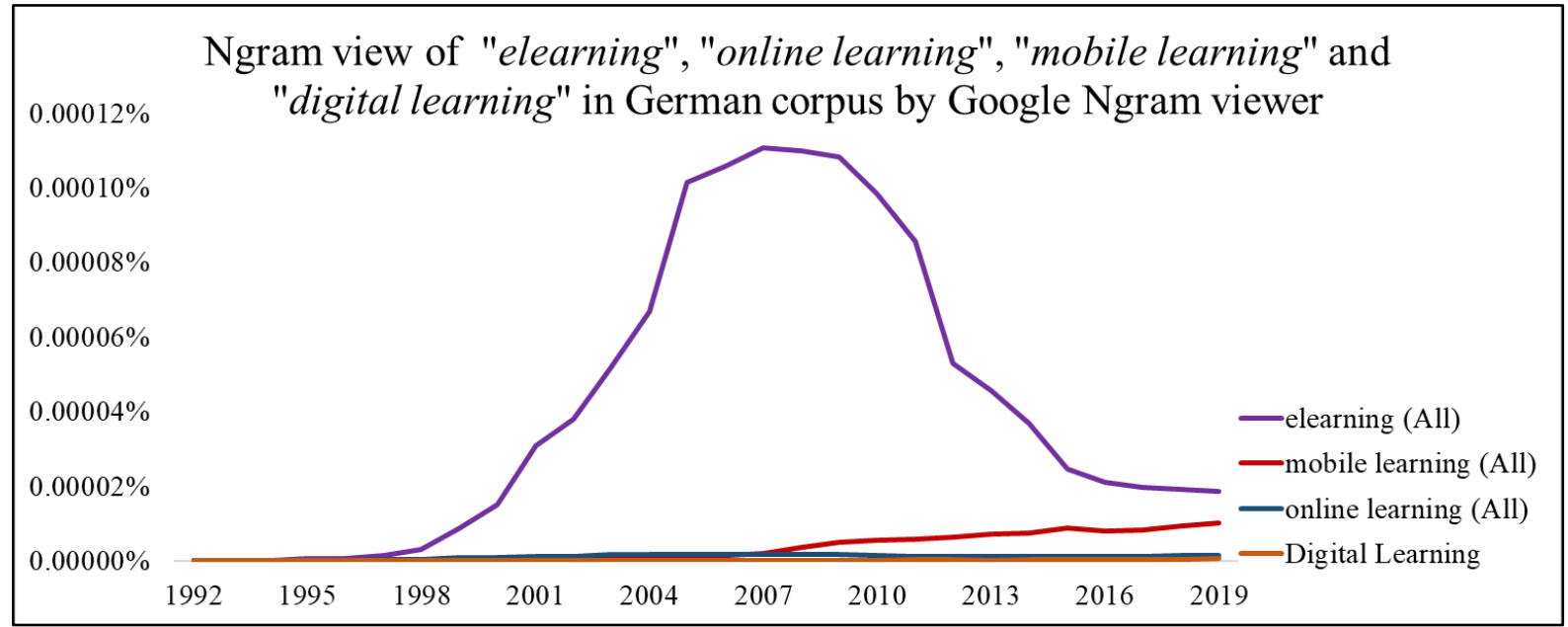

(Source: Google Ngram Viewer) (Developed By Authors)

A second but not as infectious wave can be seen in French while the pandemic spread in about ten years from English to German and Italian then to French and Spanish, sweeping across the western part of the continent. The use of digital learning is continuously increasing in English, French and Spanish implying that this term together with online learning is taking over the place of elearning in each language. 
FIGURE 10

THE NGRAM CHART OF THE TERMS "ELEARNING", "ONLINE LEARNING", "DIGITAL LEARNING" AND "MOBILE LEARNING" IN FRENCH CORPUS BETWEEN 1992 AND 2019

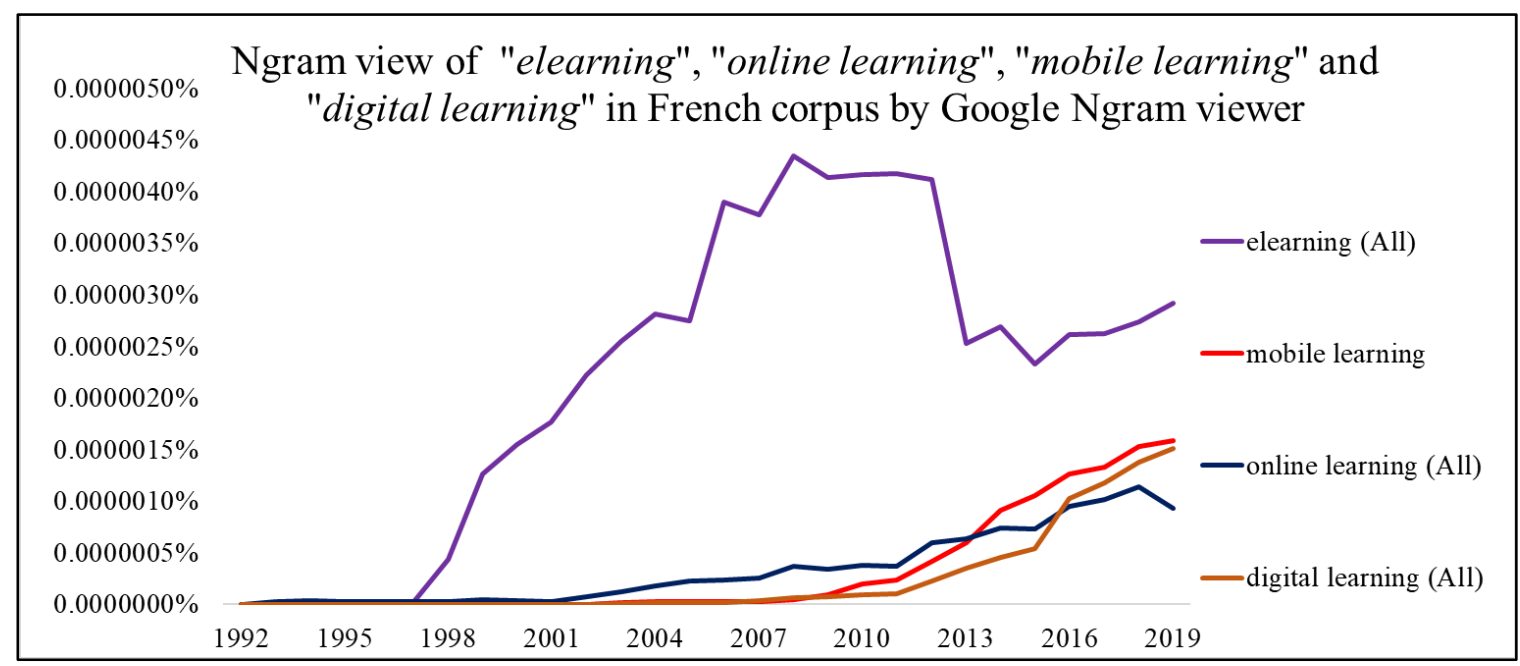

(Source: Google Ngram Viewer) (Developed By Authors)

The term digital learning is not "active" in Italian and spare in German, the virus has not reached these languages yet. After the smart boom in the middle of the first decade of the 21 st century educators were familiarized by "mobile learning" to a great extent, but the pandemic seems to have lasted for about 15 years in both British and American English as well as in Spanish - where the term was more virulent than in English. The use of the term is still virulent in German and French showing an ongoing growth while it reached its maturity in Italian.

FIGURE 11

THE NGRAM CHART OF THE TERMS "ELEARNING", "ONLINE LEARNING", "DIGITAL LEARNING" AND "MOBILE LEARNING” IN SPANISH CORPUS BETWEEN 1992 AND 2019

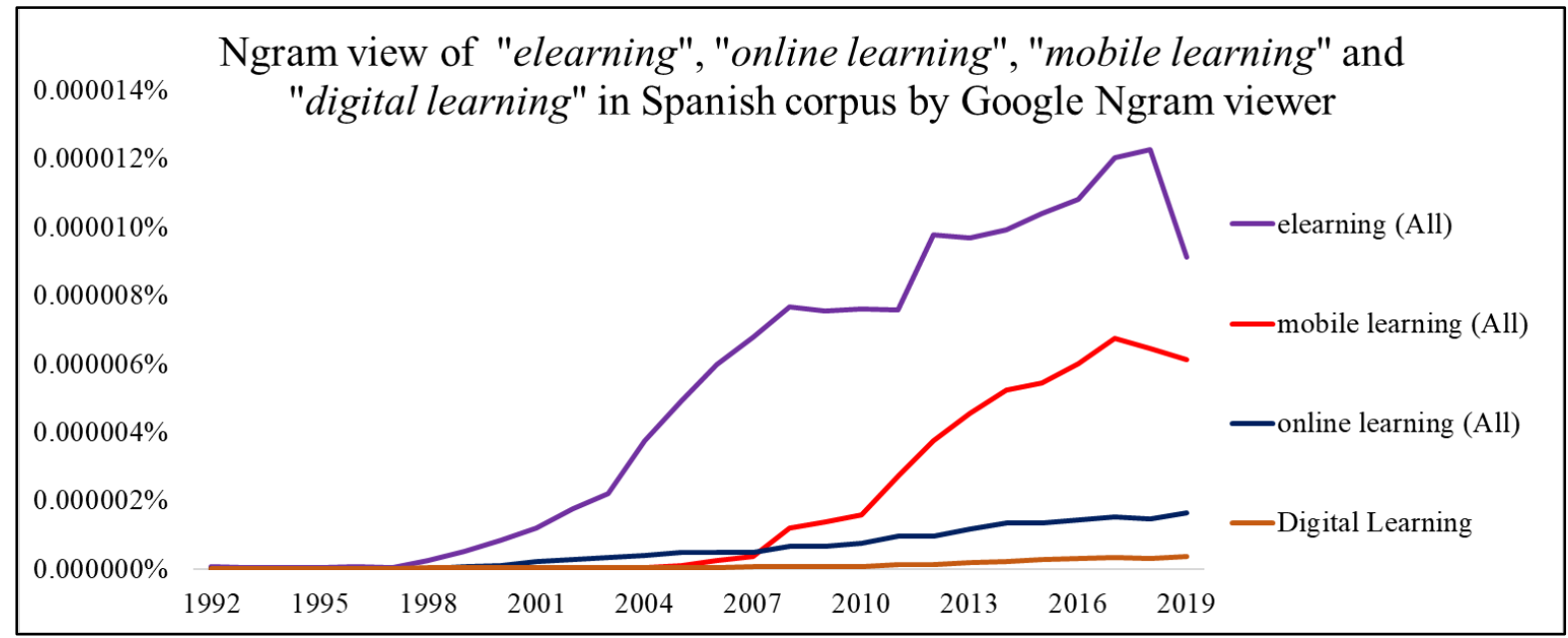

(Source: Google Ngram Viewer) (Developed By Authors) 
FIGURE 12

THE NGRAM CHART OF THE TERMS "ELEARNING", “ONLINE LEARNING", "DIGITAL LEARNING" AND “MOBILE LEARNING" IN ITALIAN CORPUS BETWEEN 1992 AND 2019

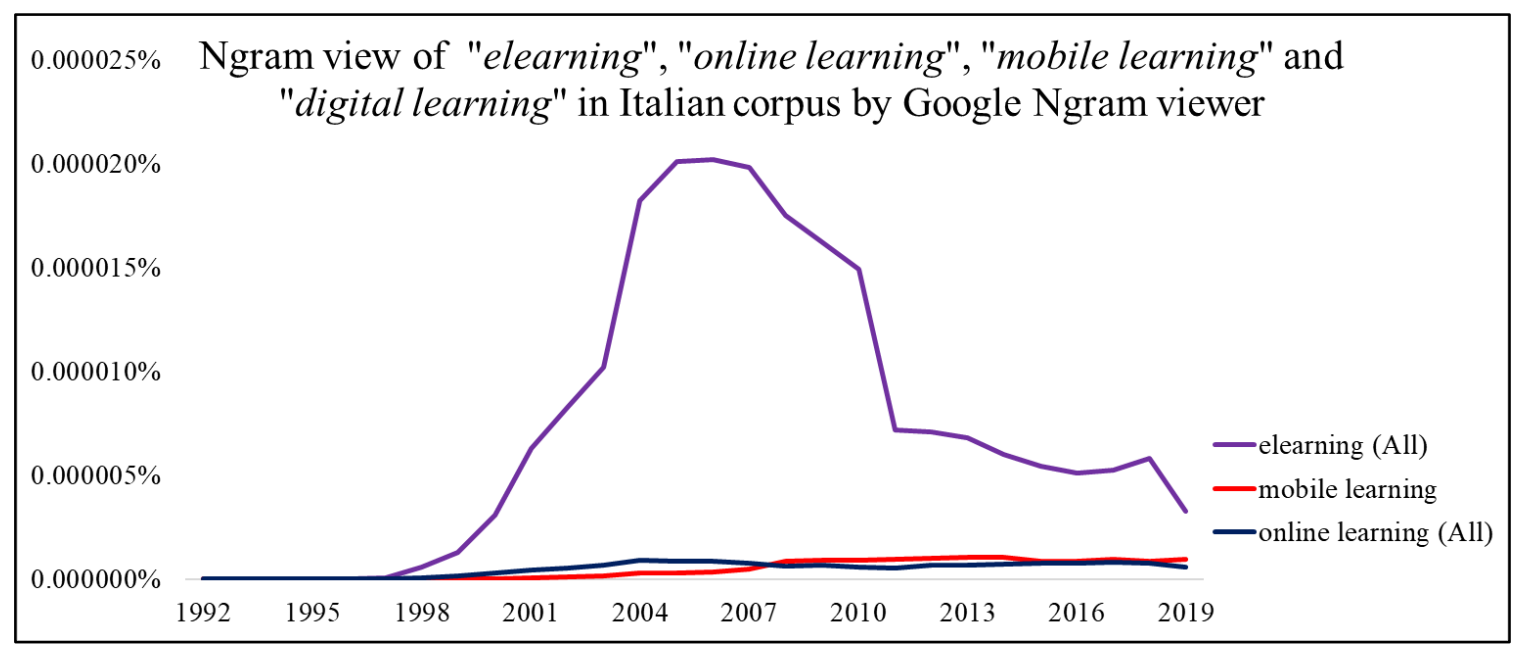

(Source: Google Ngram Viewer) (Developed By Authors)

Finally, the relative frequencies of the usage of blended learning and hybrid learning were searched and compared between the American and British English, German, French, Italian and Spanish corpus (Figure 13, Figure 14). According to the search result by Google Ngram viewer the term hybrid learning has not reached the continent to a noticeable extent, since no data was found in the German, French, Italian and Spanish corpus, while the term had two waves in the American and British corpus with a five-year time shift being more virulent in the British corpus. Hybrid learning seems to creep into use at present with the current COVID-19 pandemic situation since before the closure of secondary and tertiary educational institutions some universities introduced the mixture of in-class lessons with live streaming.

\section{FIGURE 13 \\ NGRAM VIEW OF BLENDED LEARNING AND HYBRID LEARNING IN AMERICAN AND BRITISH ENGLISH CORPUS BETWEEN 1985 AND 2019}

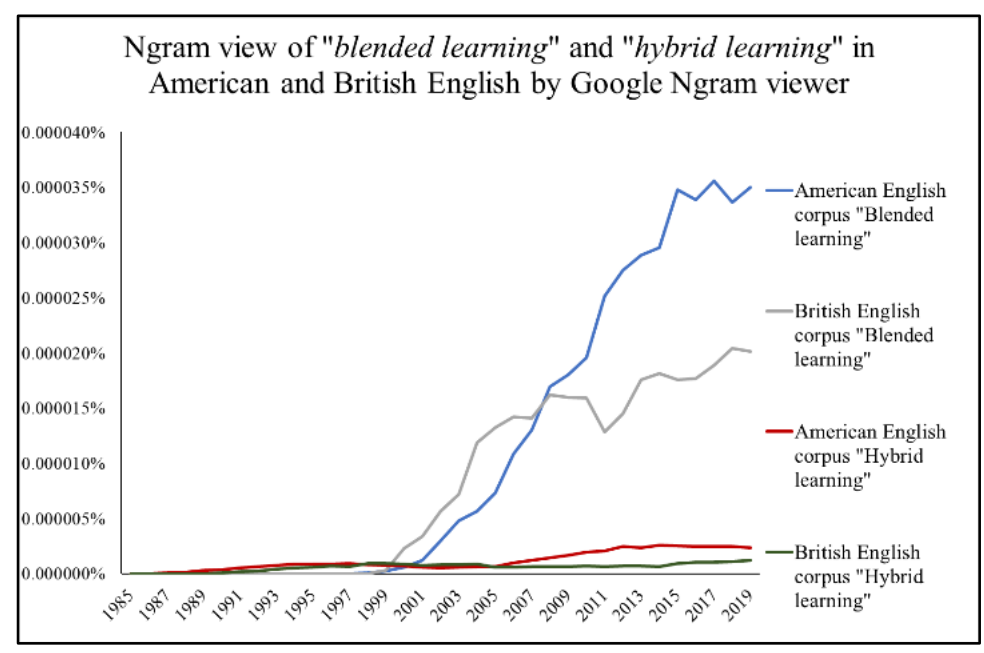

(Source: Google Ngram Viewer) (Developed By Authors) 


\section{FIGURE 14 \\ NGRAM VIEW OF BLENDED LEARNING IN FRENCH, GERMAN, SPANISH AND ITALIAN CORPUS BETWEEN 1985 AND 2019}

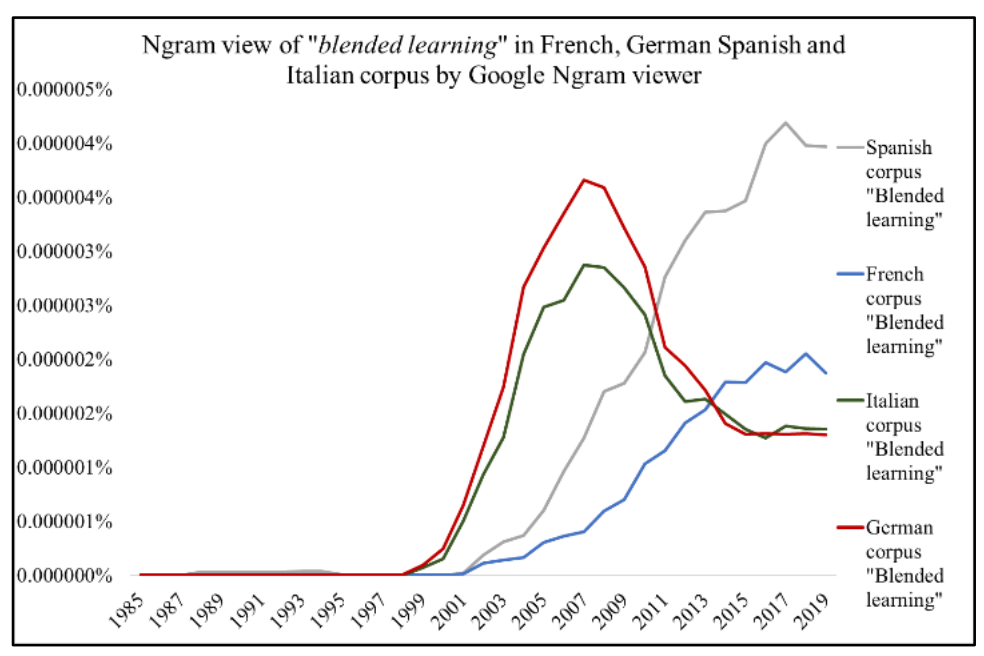

(Source: Google Ngram Viewer) (Developed By Authors)

The term blended learning has not lost its infectious nature in these corpuses being more used in the American English corpus. Looking at the continental usage in the French, German, Italian and Spanish corpus, the boom of the term burst out at the end of the century in the German and Italian corpus, and the life of the term followed a similar path, losing its importance after a decade. In the meantime, the rocketing usage of the term could be noticed in the Spanish as well as in the French corpus being quite infectious and still on the upswing.

\section{CONCLUSION}

The digital transformation and development speeds up and changes the approaches to concepts related to the mode and method of teaching. The terms used for the different type of teaching vary and change over type depending on the rate of digitalization and the needs of students. However, education can have such sudden impetus that requires a sudden qualitative jump resulting in sweeping out terms and concepts and replacing them by other ones.

Most of the terms listed and explored in the chapters can be unequivocally paired with ICT development and the evolutionary and revolutionary stages of the EMR model. For instance, these are CALL with the introduction of computers and isolated systems, mobile learning with the smart boom and the methodological redesign, while elearning and online learning with the spreading of internet and networks These terms went viral through methodological redesign to educational scope redefinition. Digital learning proved to be such a general term that its usage shows a slow but ever-increasing progress. Distance learning as being a term not directly linked to computer and communication as well as network technologies has lost its power, however, online learning seems to have combatted the other narratives, mostly linked to educational scope redefinition during the COVID-19 pandemic and proves to be the most virulent at present.

The present research gives possible input to further future research on the methodological changes in education and options for higher involvement of digital technologies and exploring the radical changes in the mode of delivery.

Using the tool of narratives and the epidemic behaviors the paper explored the educational methodology redesign process, defined and compared terms related to the mode and method of teaching and learning and looked into the changes in narratives due to the ICT development and digitalization. 


\section{REFERENCES}

Anohina, A. (2005). Analysis of the terminology used in the field of virtual learning. Educational Technology \& Society, 8(3), 91-102.

Basak, S., Wotto, M., \& Be' langer, P. (2018). E-learning, M-learning and D-learning: Conceptual definition and comparative analysis. E-Learning and Digital Media, 15(4), 191-216. doi:https://doi.org/10.1177/2042753018785180

Bates, A.W. (2005). Technology, E-learning and Distance Education. London: Routledge.

Brown, T., \& Mbati, L. (2015). Mobile learning: Moving past the myths and embracing the opportunities. International Review of Research in Open and Distributed Learning, 16(2), 115-135. doi:https://doi.org/10.19173/irrodl.v16i2.2071

Carliner, S. (2004). An Overview of Online Learning. Amherst, MA: HRD Press Inc.

Cowden, G., Mitchell, P., \& Taylor-Guy, P. (2020). Remote learning. Rapid literature review. Association of Independent Schools NSW \& Australian Council for Educational Research. doi:https://doi.org/10.37517/978-1-74286-610-9

Cronje, J. (2020). Towards a new definition of blended learning. The Electronic Journal of e-Learning, 18(2), 114-121. doi:doi:10.34190/EJEL.20.18.2.001

Dorsah, P. (2021). Pre-service teachers' readiness for emergency remote learning in the wake of COVID19. European Journal of STEM Education, 6(1), 1-12. doi: https://doi.org/10.20897/ejsteme/9557

Ferguson, J., \& Wilson, J. (2001). Process re-design and online learning. International Journal of Educational Technology, 2(2), 1-11. Retrieved October 4, 2020, from https://pureportal.strath.ac.uk/en/publications/process-re-design-and-online-learning

Gogh, E., Racsko, R., \& Kovari, A. (2021). Experience of Self-Efficacy Learning among Vocational Secondayry School Students. Acta Polytechnica Hungarica, 18(1), 101-119. Retrieved from http://acta.uni-obuda.hu/Gogh_Racsko_Kovari_108.pdf

Guri-Rosenblit, S., \& Gros, B. (2011). E-Learning: Confusing terminology, research gaps and inherent challenges. The International Journal of E-Learning \& Distance Education, 25(1).

Hegyesi, F. (2013). Moodle in higher education and at Óbuda university. In A. Szakál (Ed.), IEEE 8th International Symposium on Applied Computational Intelligence and Informatics (SACI) (pp. 6771). Timisoara: IEEE Hungary. doi: 10.1109/SACI.2013.6608940

Hodges, C., Moore, S., Lockee, B., Trust, T., \& Bond, A. (2020, June 5). The difference between emergency remote teaching and online learning. EDUCAUSE Review. Retrieved January 31, 2021, from https://er.educause.edu/articles/2020/3/the-difference-between-emergency-remoteteaching-and-online-learning

Hrastinski, S. (2109). What do we mean by blended learning? TechTrends, 63, 564-569. doi:https://doi.org/10.1007/s11528-019-00375-5

Jacqueline, G., \& Brooks, M.G. (1999). In search of understanding: The case for constructivist classrooms. Alexandria, Virginia: Association for Supervision and Curriculum Development.

Kaur, M. (2013). Blended learning - Its challenges and future. Procedia-Social and Behavioural Sciences, 93, 612-617. doi:https://doi.org/10.1016/j.sbspro.2013.09.248

Kolakowski, M., Hackbarth, G., Ebrahim, S., \& Walker, E., II. (2020). A Contextual Approach to ELearning Delivery in Higher Educational Institution Learning Organizations. Journal of Higher Education Theory and Practice, 20(11), 12-24. doi:https://doi.org/10.33423/jhetp.v20i11.3759

Koohang, A., \& Harman, K. (2005). Open source: A metaphor for e-learning. Informing Science Journal, $8,75-86$.

Kothamasu, K. (n.d.). Odl Programmes through M-learning technology. Retrieved January 26, 2021, from https://wikieducator.org/images/0/04/Kiran_Kumar_Kothamasu.pdf

Lin, Y., Michel, J., Aiden, E., Orwant, J., \& Broc, W. (2012). Syntactic annotations for the Google books Ngram corpus. Proceedings of the 50th Annual Meeting of the Association for Computational Linguistics (pp. 169-174). Jeju. 
McCrindle, M. (2018). The ABC of XYZ: Understanding the global generations (3rd ed.). McCrindle Research Pty Ltd. Retrieved October 4, 2020, from https://www.westga.edu/ distance/ojdla/spring11/miller11.html

Miller, D., \& Padgett, T. (1998). Redesigning the learning environment for distance education: An integrative model of technologically supported learning environments. Distance Journal Administration, Online Journal of Distance Learning Administration, 1(1).

Ozuorcun, N., \& Tabak, F. (2002). Is M-learning versus E-learning or are they supporting each other? Procedia - Social and Behavioral Sciences, 46, 299-305. doi:https://doi.org/10.1016/j.sbspro.2012.05.110

Park, Y. (2011). A pedagogical framework for mobile learning: Categorizing educational applications of mobile technologies into four types. The International Review of Research in Open and Distributed Learning, 12(2), 78-102. doi:https://doi.org/10.19173/irrodl.v12i2.791

Parson, D. (2014). The future of mobile learning and implications for education and training. In M. Ally, \& A. Tsinakos (Eds.), Increasing learning through mobile learning (pp. 217-229). Vancouver: Commonwealth of Learning and Athabasca University.

Picciano, A.G. (2001). Distance learning: Making connections across virtual space and time. Upper Saddle River, NJ: Merill: Prentice Hall.

Shiller, R.J. (2020). Narrative Economics: How Stories go viral and drive major economic forces. Princeton, New Jersey: Princeton University Press.

Simonson, M., \& Seepersaud, D.J. (2019). Distance Education, Definition and Glossary of Terms (4th ed.). Charlotte, NC: Information Age Publishing Inc.

Steele, C. (2020, December 10). Leading Learning. Retrieved January 27, 2021, from Hybrid vs. Blended Learning: The difference and why it matters. Retrieved from https://www.leadinglearning.com/hybrid-vs-blended-learning/

Tick, A. (2006). A web-based e-learning application of self study multimedia programme in military English. Proceedings of the 3rd Romanian-Hungarian Joint Symposium on Applied Computational Intelligence (SACI) (pp. 621-633). Timisoara: IEEE Hungary Section.

Venkatraman, N. (1994). IT-enabled business transformation: From automation to business scope redefinition. Sloan Management Review, 35, 73-87. Retrieved October 4, 2020, from https://sloanreview.mit.edu/article/itenabled-business-transformation-from-automation-tobusiness-scope-redefinition/

Yigit, T., Koyun, A., Yuksel, A., \& Cankaya, I. (2014). Evaluation of blended learning approach in computer engineering educatio. Procedia - Social and Behavioral Sciences, 141, 807-812. doi:https://doi.org/10.1016/j.sbspro.2014.05.140 